\title{
רem Orixá no Samba: Clara Nunes e A PRESENÇA DO CANDOMBLÉ E DA UMBANDA NA MÚSICA POPULAR BRASILEIRA*
}

\author{
Rachel Rua Baptista Bakke
}

Muitas vezes é possível entrar em contato com valores de uma determinada religião sem que, necessariamente, a pessoa seja adepta ou tenha vivido alguma experiência nesse universo religioso específico. Isso ocorre, principalmente, quando símbolos, experiências, valores e elementos do ritual ultrapassam os limites dos locais de culto tais quais terreiros, igrejas, templos etc., e aparecem como contexto em reportagens de jornal ou revistas, em obras de arte, nas peças teatrais, ou em livros e músicas. Nessa perspectiva, a Música Popular Brasileira (MPB) é um importante veículo divulgador do universo religioso afro-brasileiro, mais especificamente a umbanda e o candomblé, contribuindo para a conformação de um imaginário sobre o mesmo que se encontra diluído na cultura nacional.

Alguns autores, como Moura (1983), Sodré (1979) e Sandroni (2001), ao reconstruírem a formação do samba urbano carioca no início do século XX, explicitaram as relações entre esse e os terreiros da Cidade Nova. As conhecidas casas das "tias baianas", como da Tia Ciata, eram ao mesmo tempo moradia, local de culto e de lazer, e funcionavam como esteio tanto para o desenvolvimento do samba quanto do próprio candomblé. Outros autores, como Amaral \& Silva (2004) e Prandi (2000), procuram estender a análise dessas relações entre música e religiões afro-brasileiras às décadas mais recentes.

Considerando a música popular um importante meio difusor dos valores 
religiosos afro-brasileiros para além dos muros dos terreiros, procuraremos a partir da trajetória artística de Clara Nunes - importante intérprete que marcou época no mercado fonográfico brasileiro como a primeira mulher a vender mais de cem mil cópias de disco com um repertório reconhecidamente rico em referências ao candomblé e à umbanda - entender algumas relações significativas entre a MPB e as religiões afro-brasileiras, ressaltando-se as influências dessas religiões na construção da carreira dessa intérprete, assim como para a divulgação e elaboração de um imaginário positivo dessas religiões no universo geral da cultura nacional.

\section{Se vocês querem saber quem eu sou}

Clara Nunes nasceu em $1943^{1}$ numa pequena cidade mineira próxima a Belo Horizonte, chamada Paraopeba. Seu pai era violeiro e cantador de Folia de Reis, por isso, desde cedo, Clara entrou em contato com a música e com o universo da cultura popular.

Aos dezesseis anos, já órfã, mudou-se para Belo Horizonte, a fim de continuar seus estudos. Foi nessa cidade que iniciou sua carreira artística, num concurso de calouros promovido pela Fábrica de rádios e televisões $\mathrm{ABC}$, chamado "A voz de ouro ABC", em 1960. Venceu a fase regional desse concurso, conseguindo assim um emprego na Rádio Inconfidência, onde apresentava um programa chamado "Clara Nunes convida".

O sucesso na rádio Inconfidência lançou à televisão e, em 1963, estreou um programa de variedades na TV Itacolomi, no qual a cantora/apresentadora discutia as notícias de Belo Horizonte e entrevistava artistas de reconhecimento nacional como Ângela Maria e José Messias. Essa experiência na televisão ajudou a consolidar a carreira local da cantora e lhe proporcionou os primeiros contatos no Rio de Janeiro, pois alguns de seus entrevistados ilustres lhe abriram as portas do mercado carioca com convites para participar em eventos e programas realizados nessa cidade. Participou, por exemplo, do Programa de José Messias, na TV Continental, e em 1965 foi convidada por Milton Miranda, diretor artístico da Odeon, para realizar um teste no estúdio da gravadora. Aprovada, mudou-se para o Rio de Janeiro.

O início da carreira nacional de Clara Nunes foi bastante difícil. Como o gênero musical de maior sucesso na época era o bolero, a Odeon tinha a intenção de transformá-la numa espécie de "Altemar Dutra de saias", porém, apesar do investimento em marketing - como a aparição em programas de auditório de sucesso da época e da gravação de seu primeiro Long Play (LP) solo, em 1966 A voz adorável de Clara Nunes -, a imagem pretendida pela gravadora não agradou o público, e o sucesso ainda demoraria a acontecer.

Clara Nunes fazia o que os produtores da Odeon lhe indicavam. Por isso, 
transitou por vários gêneros musicais - bolero, romântico, jovem-guarda - até que em 1968, com a ajuda de Ataulfo Alves, convenceu os diretores da Odeon a deixá-la gravar samba, gênero até então "em baixa" no mercado fonográfico.

A gravação de músicas como "Você passa e eu acho graça", de Ataulfo Alves e Carlos Imperial, fez com que a cantora experimentasse um certo sucesso, porém o êxito não foi do tamanho esperado pela Odeon. Apesar disso, Clara insistiu em sua carreira, participando de alguns festivais de música do circuito universitário e retomando o papel de crooner, em boates da moda. Sua carreira seguiu oscilando entre sucessos e fracassos; ela não conseguia criar uma imagem pública, muito menos cultivar um público cativo.

Entre os anos de 1969 e 1971, sua sorte começou a se alterar. Nesse período, ocorreram transformações tanto em sua vida profissional, quanto na espiritual. A cantora nasceu católica, foi batizada e fez primeira comunhão, mas, por volta dos 14 anos, teve os primeiros contatos com a religião espírita, por influência de uma prima, kardecista. Quando se mudou para o Rio de Janeiro, conheceu a umbanda, religião que mais tarde veio adotar, conforme declarou numa entrevista concedida ao radialista Edson Guerra, da Rádio Bandeirantes, em 1981. “(...) ao me mudar para o Rio, eu tomei contato, assim mais de perto com a umbanda, e depois de uma viagem à África, sabe, eu voltei e me encontrei na umbanda." (Fonte: gravação particular de colecionador).

Pode-se dizer que a viagem à África funcionou como um divisor de águas tanto na vida espiritual quanto na carreira dessa artista. $\mathrm{Na}$ volta, inspirada por essa experiência, Clara elaborou, com a ajuda do radialista Adelzon Alves, uma nova proposta de carreira que foi imediatamente apresentada a Odeon. A gravadora não viu com bons olhos esse novo projeto, afinal era a primeira produção de Adelzon Alves, a proposta era arrojada e o repertório da cantora seria radicalmente mudado, mas, com a insistência de Clara Nunes, o projeto foi levado adiante. Era o início da consolidação de uma carreira artística fortemente marcada por um estilo e uma imagem que aproximava a cantora do samba e da umbanda, o que a levou a ser rotulada como "Sambista, Cantora de Macumba".

(...) Tinha que ser uma carreira planejada e que tivesse como base a imagem afro-brasileira da Carmen Miranda. (...) Eu levava ela para a casa do Candeia mas também levava para a casa da Vovó Maria Joana Rezadeira, que era uma mãe-de-santo que havia no Império Serrano. Era um ícone. A Clara também era muito amiga do pai Edu (...). Aí tinha um costureiro chamado Geraldo Sobreira, que já era amigo dela, e foi desenvolvendo aquele estilo, aquelas roupas. Então, a carreira tomou esse rumo em função de ela ser levada para o lado do samba e de já ter amizade com pessoas ligadas 
à umbanda, como o caso da Vovó Maria Joana Rezadeira. (Fonte: www.opovo.com.br - jornal O Povo, caderno Arte \& Vida. Consultado em: 04/2003).

Segundo o radialista, após a morte de Carmen Miranda, nenhuma outra artista construiu uma carreira baseada numa imagem afro-brasileira. A idéia, então, era aproveitar esse espaço deixado vago, aproximando Clara Nunes das escolas de samba e seus compositores; diferenciando-a assim de outras cantoras de sucesso da época, como Elis Regina.

O "retorno à África", como fonte de tradição e de legitimidade, foi tão significativo para a carreira de Clara Nunes, como foi, e ainda é, para as religiões afro-brasileiras, em especial o candomblé. No processo de formação e legitimação dessas religiões, a idéia de "retorno à África" exerceu um importante papel, uma vez que esse continente funcionou, e ainda funciona, como uma fonte de tradição cultural. Retornar a ele e lá sorver conhecimento sobre as práticas rituais, o awô (segredo) do axé africano, é motivo de prestígio e gera, para aqueles que fizeram esse trajeto, importante capital social perante a comunidade religiosa. Como aponta os pesquisadores Maria do Carmo Brandão e Roberto Motta: "Nessa religião em que tudo é volta, ou diz ser volta, o retorno à África é a volta fundamental, é a fonte e a origem de toda religião verdadeira" (Brandão \& Motta 2002:60) ${ }^{2}$.

Nos anos de 1970 e 1980 o candomblé ganhou as ruas, tornou-se enredo de escola de samba, alegoria de blocos carnavalescos em Salvador, elemento de trama de "novela das oito", tema de música interpretadas por cantores populares da MPB etc. O "retorno à África", nesse contexto, ganhou outros contornos que extrapolaram os limites da religião. Nesse período, muitos artistas, assim como os sacerdotes de outrora, dirigiram-se à África, uma África muitas vezes mítica e idealizada, no afã de redescobrir uma essência de brasilidade, sobretudo negra, que passou a ser cantada nas rádios e TVs.

Clara Nunes, ao lado de Martinho da Vila, foi um desses artistas cuja carreira e vida foram fortemente marcadas por esse retorno. Sua conversão à umbanda e as experiências vividas nas viagens que empreendeu à África foram apontadas pela própria cantora, em entrevistas concedidas ao longo da vida, como eventos que mobilizaram as mudanças em sua trajetória a partir de 1969 .

Começou assim um processo de construção de uma imagem artística que associava a cantora às tradições culturais afro-brasileiras. Os símbolos utilizados para articular a obra da cantora com o universo cultural afro-brasileiro, e mais tarde brasileiro, foram essencialmente retirados do candomblé e da umbanda, e apareciam nas músicas que cantava, nas suas performances em shows, e nas reportagens de jornais e revistas que, ao divulgarem elementos da vida cotidiana e íntima de Clara, revelavam para um público maior o estilo de vida do povo de santo. 


\section{Eu sou a Tal Mineira}

A carreira artística de Clara Nunes pode ser dividida em três momentos distintos. O primeiro se caracterizou, como já foi dito, na busca por um espaço no mercado fonográfico brasileiro, quando tentaram transformá-la numa cantora de boleros. O segundo, foi marcado pela "descoberta da África" e da umbanda, quando Clara se aproximou de Adelzon Alves e imprimiu um novo estilo à sua imagem artística, chegando a ser reconhecida pela imprensa como "cantora de macumba" . A última etapa de sua carreira caracterizou-se pelo desejo de ser reconhecida como cantora popular brasileira, quando a idéia de mestiçagem passa a ser central na concepção de identidade nacional que sua obra divulga, e o caminho através do qual as religiões afro-brasileiras se inseriam no universo da cultura nacional.

Produzida por Adelzon Alves, Clara passou a se apresentar só de branco, gravou alguns pontos de umbanda e candomblé, fez curso de expressão corporal e dança afro e procurou se aproximar de alguns compositores como Cartola, Nelson Cavaquinho, Candeias, Romildo e Toninho, Martinho da Vila, João Nogueira entre outros. Foi também nesse período que começou a freqüentar as escolas de samba do Rio, quando conheceu a Portela que se tornou sua escola do coração.

Nas diversas entrevistas que concedia sobre sua carreira e vida pessoal, sua ligação com a umbanda ou o candomblé estava quase sempre presente. A cantora declarava abertamente o seu pertencimento a essas religiões, ainda que muitas vezes evitasse revelar detalhes de suas atividades religiosas.

Não raro, nessas entrevistas apareciam especulações sobre se a cantora era ou não iniciada. Em, pelo menos, duas reportagens publicadas no jornal Folha de São Paulo em 11/09/19754 e na Revista Amiga de 20/04/1983, falou-se abertamente que a cantora era filha de santo de Pai Edu, babalorixá do terreiro Palácio de Iemanjá, em Olinda, em cujas paredes são exibidas orgulhosamente fotos do ritual no qual a cantora teria sido consagrada a Oxum, no rio Capibaribe ${ }^{5}$. Em outros momentos, as reportagens discutem de quem Clara Nunes seria, enfim filha, se dos orixás Ogum e Iansã, conforme cantava na música "Guerreira", ou de Oxum, para quem foi consagrada, segundo Pai Edu.

O que nos chama atenção é que, pela análise do material divulgado na imprensa da época, parece não haver uma separação nítida entre a vida pública e a vida privada da artista em relação às suas opções religiosas. Clara gostava de afirmar que tinha prazer em cantar as coisas da sua fé, revelava abertamente seus tabus religiosos, suas obrigações mostrando como a crença norteava sua maneira de vestir, de entrar no palco, de cantar etc.

Sou muito supersticiosa. Não visto preto, não deixo porta de armário aberta, não coloco sapatos em cima do armário e só canto de branco. 
É uma cor que transmite paz, coisa boa para o público. Dá uma aura legal. Sou também muito mística. Para começar, na minha religião, quando a gente faz a cabeça, assume certas obrigações e deve cumprí-las. Eu sigo tudo à risca. Mesmo as coisas que eu adoro, eu deixo de fazer. Comer doce de abóbora ${ }^{6}$, por exemplo. É comida do meu santo. Eu não posso comer. Não como. (Fonte: www.claraguerreira.hpg.ig. Consultado em 05/2003)

Essas declarações despertavam a curiosidade do público em geral, que acabava conhecendo, assim, vários aspectos da religião como os tabus alimentícios, os rituais de iniciação, as "mudanças de santo" etc.

No período entre 1969 e 1974, Clara Nunes, junto com Adelzon Alves, construiu e consolidou uma imagem artística que a associa fortemente à umbanda e ao candomblé. Gravou os LPs Clara Nunes; Clara, Clarice e Clara; Clara Nunes: Brasília e Alvorecer, com o qual quebrou um antigo tabu do mercado fonográfico brasileiro que dizia que mulher não vendia discos, com a marca de aproximadamente 400 mil cópias vendidas, números semelhantes aos de Roberto Carlos, considerado o "Rei das vendagens".

Nesses discos foram gravados sucessos como "Ê Baiana", "Misticismo da África ao Brasil", "Ilu Ayê", "Tributo aos orixás", "Morena do Mar", "Homenagem a Olinda", "Recife e Pai Edu", "Sindorerê", "Nanaê, Nanã Naiana" e "Conto de Areia". Foi nessa época que Clara participou dos shows "O poeta, a moça e o violão" (1973) com Vinícius de Moraes e Toquinho7; "Brasileiro: profissão esperança" (1974), com Paulo Gracindo e direção de Bibi Ferreira; e representou o Brasil, junto com o conjunto "Nosso Samba", no Festival do Mercado Internacional do Disco e da Edição Musical (MIDEM) de 1974, em Cannes, onde cantou a música "Tributo aos Orixás" e concedeu uma entrevista sobre seu "figurino afro" à edição francesa da revista Vogue.

O término do relacionamento pessoal com Adelzon Alves, ao final de 1974, também significou o término da parceria profissional. No ano seguinte, a cantora gravou o disco de maior vendagem de sua carreira, Claridade, cuja faixa de grande sucesso foi a composição de Toninho e Romildo, "A deusa dos orixás".

Ainda em 1975, Clara Nunes conheceu Paulo César Pinheiro, que se tornou seu produtor musical, o principal compositor de suas músicas e marido. Esse encontro marca o início da terceira e última fase de sua carreira. O casamento com Paulo César Pinheiro também significou mudanças em sua vida espiritual, pois acarretou em seu afastamento do terreiro de Pai Edu.

A essa altura, Clara Nunes já era uma cantora de grande reconhecimento nacional e seu casamento foi um acontecimento coberto pela imprensa. Um dos assuntos mais comentados sobre o evento foi o fato de Clara ter convidado um padre, ou invés de um pai-de-santo, para celebrar a cerimônia. 
Em entrevista, Pai Edu nos relatou que só ficou sabendo do casamento de Clara pela Revista Amiga, o que muito lhe chateou, pois, segundo o pai-desanto, a cantora tinha lhe dito que se casaria em seu terreiro. À época, Clara respondeu em uma entrevista concedida ao Jornal Folha de São Paulo de 11/09/ 1975 que Pai Edu havia sido envolvido pela imprensa, pois ela nunca lhe prometeu casar lá, apenas disse que um dia, quando pudesse, iria ao seu terreiro para ser abençoada. Fato é que, após esse episódio, Clara se afastou da casa de Pai Edu e não foram encontrados indícios de que ela tenha se ligado diretamente a outro sacerdote, apenas de que freqüentava esporadicamente o terreiro de Vovó Maria Joana Rezadeira, a Tenda Espírita Cabana de Xangô.

Assim como o seu casamento, a inauguração de seu teatro também gerou polêmica porque a cantora mais uma vez convidou um padre e não um pai-de-santo, para "batizar" o estabelecimento, como conta a reportagem "Quando o palco é o melhor investimento", publicado na Folha de São Paulo em 09/05/1977:

(...) Deus, aliás, é uma presença constante na conversa da cantora, apesar do misticismo que acompanhou sua carreira, até tempos atrás, ter desaparecido aparentemente. As roupas brancas de filha-desanto foram substituídas por estampados de gosto duvidoso. Nos cabelos nada de flores brancas mas tinta acaju laranja e, para completar, o teatro foi batizado por um padre, trazido de Minas por Clara. Quando lhe lembram da contradição entre a Clara de algum tempo atrás - acusada até de explorar sua religião, cantando 'pontos' - e a de hoje, que traz um padre mineiro para lhe benzer o teatro, ela diz que sua devoção é Oxalá no candomblé e Cristo no catolicismo. 'É nele que eu creio. Padre João (o que veio de Minas) sabe disso. Sabe que meu pai de cabeça é Oxalá. Mas, veio porque respeita, como eu, todas as religiões. Não importa se o teatro é batizado por um padre ou por um pai-de-santo. O importante é que ele foi abençoado por Oxalá'.

Acreditando no esgotamento do estilo afro, com o qual alcançou sucesso, Clara foi pouco a pouco mudando seu repertório, sua forma de aparecer para o público e o discurso sobre seu trabalho. Almejava deixar de ser a "cantora de macumba" e passar a ser reconhecida como uma "cantora popular brasileira".

Eu sou uma cantora popular brasileira. É uma coisa que eu sempre lutei, sempre almejei na minha vida ser cantora popular. (...) Então eu não posso me situar se eu sou sambista. Eu sou uma cantora autêntica brasileira. (...) Não quero ser rotulada como cantora de 
macumba. Nunca gravei um ponto verdadeiro. Respeito muito minha religião. (Fonte: www.claraguerreira.hpg.ig/. Consultado em 05/2003)

É interessante notar que a passagem do estilo afro para o brasileiro não se trata de uma ruptura na obra de Clara Nunes, mas uma continuidade, ou melhor, uma ampliação de sua identidade artística. A cantora popular brasileira que Clara quer ser é aquela que canta a história de seu povo, sua arte e sua cultura. Na obra da artista, esse "brasileiro" é construído a partir da recuperação da idéia de mestiçagem. Nesse sentido, as referências às religiões afro-brasileiras vão aparecer nos momentos em que se pretende falar da contribuição negra na formação cultura brasileira.

Nesse período, que vai de 1975 à 1983, a cantora "puxou na avenida" o samba enredo da Portela "Macunaíma, herói da nossa gente" (1975), gravou os LPs Canto das Três Raças (1976), As Forças da Natureza (1977), Guerreira (1978), Esperança (1979), Brasil Mestiço (1980), Clara Nunes (1981) e Nação (1982). Cantou músicas como "Canto das Três Raças", "Fuzuê", "Embala Eu", "Banho de Manjericão", "Brasil mestiço santuário da fé", "Senhora das Candeias", "Guerreira", "Ijexá", "Afoxé para Logum" e "Mãe África".

Em 1976, estreou o show Canto das Três Raças e, em 1981, Clara Mestiça. Nesse último - dirigido por Bibi Ferreira, com roteiro musical de Paulo César Pinheiro e Maurício Tapajós, e cenário de Elias Andreato -, Clara procurou apresentar um repertório que traduzisse a idéia que tinha sobre o Brasil, um país culturalmente mestiço, por isso inicia o show interpretando uma música dos índios Krahó, passa para o afro com "Sindorerê", de Candeias, canta sambas de compositores cariocas, músicas paulistas, vai ao nordeste interpretando frevos, forrós, bumba-meu-boi e sambas de roda. Ao final, retorna à África interpretando "Morro Velho" de Milton Nascimento.

Alguns paralelos podem ser traçados entre a trajetória artística e religiosa de Clara Nunes e a identidade musical nacional. Ela caminha progressivamente do bolero e da música romântica, de forte influência estrangeira, em direção a estilos cada vez mais tidos como brasileiros, marcha-rancho, samba-canção, bossa nova, forró e, principalmente, samba. Também na religião, seu trânsito entre o catolicismo, o espiritismo, a umbanda e o candomblé aparece como exemplar da constituição do campo religioso afro-brasileiro que ela tão bem cantou como arte, mas também como opção de conversão pessoal. Neste aspecto, o fato de manter uma atitude ambígua em relação à religião afro-brasileira quando se tratava de "momentos oficiais" de sua vida também é uma característica das manifestações de adesão pública do povo-de-santo. Ter seu casamento celebrado por um padre ou seu teatro batizado também por um sacerdote católico, diz muito sobre essa "ambigüidade". Mas sua explicação sobre a correspondência entre Oxalá e Jesus parece mostrar um aspecto recorrente das correlações que 
constantemente os adeptos dos cultos afro-brasileiros fazem, o que permite seu trânsito entre esses universos.

Sou a Mineira Guerreira, filha de Ogum com Iansã: análise do material iconográfico da obra de Clara Nunes

$\mathrm{Na}$ produção artística de Clara Nunes, as referências às religiões afrobrasileiras extrapolam os ritmos e as letras das músicas e aparecem também na performance da artista em shows e aparições na TV, assim como no material de divulgação de seu trabalho como as capas e encartes do LPs. Isso é uma característica que a diferencia de outros artistas da época cujo repertório musical também apresenta muitas referências ao universo religioso afro-brasileiro.

O objetivo aqui é, a partir da analise de algumas capas de disco e de trechos de vídeo, compreender o uso que a cantora fez dos elementos religiosos para a construção de sua imagem na mídia.

Ao longo das duas últimas fases de sua carreira, elementos religiosos foram usados, intencionalmente, para que a imagem da artista fosse ligada à idéia de originalidade, de popular, e de brasileiro. Os figurinos apresentados em seus shows, sua performance em clipes e musicais, assim como as fotos estampadas em propagandas, revistas, jornais e nos encartes e capas de seus LPs, foram devidamente pensados para a consolidação de uma personagem que permitisse a cantora se identificar com um nicho específico do mercado fonográfico, que fora, primeiramente, o público consumidor de samba, e posteriormente de MPB em geral.

Nesse processo de construção de sua imagem, Clara Nunes acabou por transladar para o universo do show business, elementos significativos da umbanda e do candomblé. Ela tornou público o uso religioso de guias e pulseiras, objetos utilizados na religião, elementos performáticos contidos nos rituais religiosos (danças dos orixás, gestos e postura corporal usados em momentos específicos dos rituais etc.), entre outros.

Em cada um dos veículos empregados pela cantora para difundir sua obra (encarte e capas de LP, fotos em revistas e jornais, vídeo) aparecem elementos religiosos que - aliados ao seu gênio estourado, sua fama de lutadora e seu próprio envolvimento pessoal com o candomblé e a umbanda - contribuíram para a construção da personagem "Clara Guerreira". Aqui cabe ressaltar que essa qualificação de "Guerreira" atribuída à Clara Nunes advém, em grande parte, do fato de seus dois principais orixás de cabeça serem santos guerreiros, Ogum e Iansã.

A partir das imagens abaixo selecionadas é possível perceber de que forma o candomblé e a umbanda foram gradualmente sendo representados em capas e encartes. Tratam-se dos LPs A voz adorável de Clara Nunes (1966), Alvorecer (1974), Guerreira (1978) e Clara Nunes: a deusa dos orixás (1984), respectivamente. 


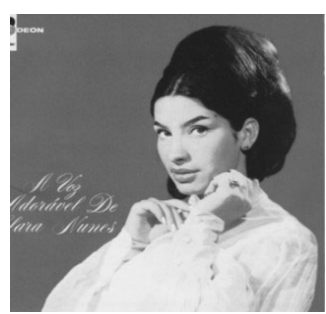

Fig. 1

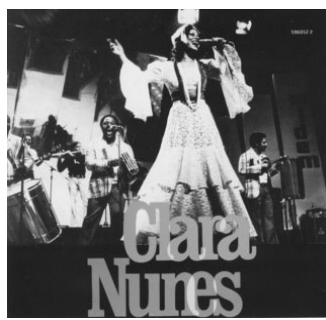

Fig. 2

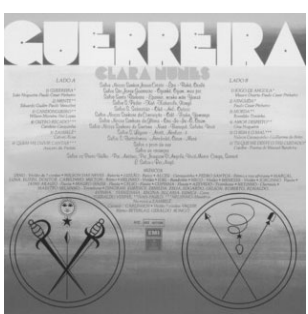

Fig. 3

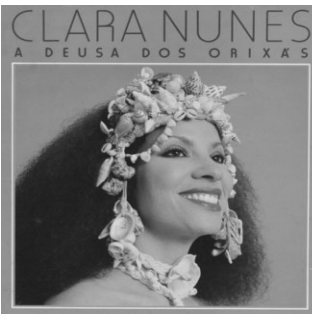

Fig. 4

A figura 1 corresponde ao primeiro LP gravado por Clara. Nela a cantora aparece com a pele bem alva, contrastando com o cabelo escuro e liso, penteado à moda das cantoras de rádio das décadas de 1940 e 1950. A intenção desse disco é apresentar uma nova cantora a um público consumidor de boleros e de baladas românticas. A segunda imagem (fig.2) refere-se ao momento em que Clara muda a direção de sua carreira, aproximando-se do samba urbano carioca e da temática afro-religiosa. É a primeira vez que Clara encarna, num LP, a personagem que se tornaria marca de sua carreira, a guerreira Filha de Ogum com Iansã. A cantora porta um traje de baiana estilizado, em seu pescoço há um conjunto de guias e sua cabeça está protegida por um pano branco que pode ser aproximado do torso ou do filá usados pelos filhos-de-santo nos terreiros de umbanda e candomblé.

Já na figura 3, há referências mais explícitas à umbanda e ao candomblé. As cores usadas na contra-capa do LP podem aludir aos orixás Oxum (amarelo) e Ogum (vermelho na umbanda) ou Iansã (vermelho no candomblé). Abaixo, também há duas representações de pontos que são riscados no chão dos terreiros de umbanda, os quais, assim como as cores, podem se referir a Ogum e Iansã. Além disso, há a transcrição da letra da música "Guerreira", na qual Clara ensina aos ouvintes as relações sincréticas entre orixás e santos católicos, e os "gritos de saudação" específicos de cada orixá.

A última imagem (fig.4) corresponde a capa de um LP póstumo lançado pela Som Livre. Nesse momento, a identificação da cantora com o candomblé já estava bastante consolidada no imaginário de seu público. A foto escolhida para ilustrar o LP foi a de Clara portando um adê (coroa) de conchas estilizado, numa clara referência aos adornos usados pelos orixás femininos no candomblé, e um quelê no pescoço, colar que a iaô (iniciada) usa durante os três primeiros meses após o ritual de iniciação, simbolizando sua ligação com o orixá.

Clara Nunes gravou vários musicais ao longo da década de 1970. Seus sucessos viraram espécies de "vídeoclipes" apresentados, juntamente com trechos de seus shows, em programas de entrevistas, como o "TV Mulher" da Rede Globo, ou em quadros de programas jornalísticos, como o "Fantástico", da mesma 
emissora. As imagens de vídeo analisadas durante a pesquisa foram gentilmente cedidas por colecionadores e fãs de Clara Nunes, que guardaram esses documentos. Em sua maioria, foram retiradas de programas póstumos com o "Especial Clara Nunes" realizado pela TV Globo em 1983, o "Clara Guerreira", da mesma emissora, em 1984, o "Só para lembrar" da TV Cultura, apresentado em 2003 lembrando os 20 anos de morte da cantora, e o "Arquivo N", apresentado também em 2003 no canal de TV a cabo Globo News.

No material coletado ao longo da pesquisa, foi possível observar que há alguns elementos recorrentes na forma de Clara Nunes se apresentar ao público, quer nos musicais (vídeoclipes), quer nos programas de televisão. Ela está sempre vestida predominantemente de branco, portando inúmeras pulseiras em seu braço esquerdo, guias e balangandãs. Mesmo quando não está gravando uma música cujo tema é religioso, ou quando está concedendo uma entrevista sobre os temas abordados em seu trabalho, Clara Nunes incorpora a personagem "Clara Guerreira", ainda que, muitas vezes, nessa personagem os elementos religiosos apareçam de forma bem discreta e estilizada.

Sua última entrevista concedida ao programa "TV Mulher" em 1982 é um dos vídeos mais representativos sobre sua performance nesse meio de comunicação. No dia da gravação, Clara Nunes foi aos estúdios da TV Globo para divulgar o espetáculo "Clara Mestiça" que estava estreando naquela ocasião em São Paulo. Num trecho do programa, a apresentadora Marília Gabriela fala sobre o figurino que a cantora porta nos shows, ressaltando seu hábito de usar branco. A relação do branco das roupas de Clara Nunes e o orixá Oxalá é o gancho a partir do qual se apresenta o musical, gravado pela intérprete, inspirado na música "Conto de Areia", faixa mais representativa do LP Alvorecer, e também, um dos sucessos mais importantes de sua carreira.

O cenário é uma representação de um barracão ${ }^{8}$. No fundo há quatro ogãs alabês ${ }^{9}$, com guias de Oxalá, tocando o atabaque que, junto a outros instrumentos do conjunto "Nosso Samba", acompanham o canto da "Guerreira". À frente dos alabês estão sete pessoas vestidas com as indumentárias dos orixás Oxum, Iemanjá, Oxalá, Nanã, Oxóssi, Ogum e Iansã, assim como se vestem aqueles que na primeira parte do xirêt ${ }^{10}$, entraram em transe e voltam, na segunda parte do ritual, do roncó ${ }^{11}$ para o barracão.

À frente de todos está Clara Nunes, que diferente das outras vezes, está usando uma roupa tradicional, e não estilizada, de filha-de-santo, com saia branca rodada bem engomada e bordada em richelieu, blusa também branca em richelieu, torso branco na cabeça e guias de Oxalá no pescoço. Ao lado de Clara Nunes há uma representação das comidas de santo, todas devidamente colocadas em gamelas numa referência ao ajeum, refeição comunitária que ocorre após o xirê.

Antes de cantar a música, Clara diz: "Sábado, Oxum e Iemanjá dividem 
cores bonitas. Oxum gosta de amarelo, Iemanjá de azul e branco. Oxum vai de feijão fradinho e champanhe, Iemanjá vai de peixe, leite de coco e manjar. E domingo é dia das crianças, e a elas ofereço o meu canto" (Fonte: material particular de colecionador).

No momento em que Clara fala desses orixás, os figurinistas que os representam são focalizados pela câmara, mostrando Oxum e Iemanjá se admirando no espelho que carregam na mão, evidenciando a vaidade dessas duas deusas. Além disso, no momento em que Clara fala das crianças, saúda a cabeça, tocando com as pontas dos dedos a testa e depois a nuca.

À medida que vai cantando a música, Clara Nunes apresenta uma coreografia que alia aos passos do samba, movimentos de braço do ijexá ${ }^{12}$. Além disso, quando canta trechos da música que se refere ao orixá Ogum, faz o gesto de sua dança que simboliza o movimento de abrir os caminhos, uma atribuição desse orixá. Quando fala de Iemanjá, saúda a cabeça com o gesto de tocar a testa, o centro da cabeça e a nuca, numa referência a esse orixá que é considerado Iyá Ori, mãe da cabeça.

As fotos presentes nas capas e encartes dos LPs e os vídeoclipes deram a Clara Nunes uma imagem de cantora das religiões negras e do Brasil, já que esse período foi marcado por uma revalorização dos temas nacionais dentro da qual a cultura afro-brasileira entrou na moda, principalmente no meio artístico.

Para divulgar seu trabalho, Clara Nunes criou uma personagem, a "Clara Guerreira", construindo assim uma imagem facilmente identificável para o público consumidor. Essa personagem, amplamente mostrada nas imagens acima analisadas, foi de fundamental importância para a divulgação e valorização do universo religioso ao qual ela se referia.

Nas capas e encartes do LP foram privilegiadas imagens estáticas da religião, são fotos de shows em que Clara usa figurino baiana reproduzindo a estética do terreiro, com intenso uso do branco e de guias; fotos de adornos de cabeça estilizando adés, torços, filás, imagens de assentamento de santo, de risco de ponto de umbanda ou de elementos da natureza, tais como o mar, o vento, a pedra, que estejam associados aos orixás. Já nas performances da cantora nos vídeoclipes, além dos componentes estáticos, também são evocados os dinâmicos do ritual. Entram em cena elementos performáticos da danças dos orixás, e uma linguagem gestual associada aos movimentos de mãos, cabeças e pés que exprimem atos de purificação, bênção, pedido de proteção, entre outros, usados pelos filhos-de-santo nos terreiros. A ambientação também se mostrou uma variável importante e fortemente influenciada pelas religiões. Freqüentemente se recorreu a espaços da natureza (matas, quedas d'água, riachos, praias, pedras etc.) para associar os orixás cantados nas músicas a esses ambientes.

Valendo-se desses recursos midiáticos, Clara Nunes imprimiu em seu trabalho a marca religiosa do candomblé e da umbanda. E mais do que isso, em 
pleno período da ditadura marcado pela censura dos meios de comunicação e da produção artística, fez essas religiões chegarem a um público mais amplo que os do terreiro de uma forma positiva, sem folclorizá-las, apresentando o lado bonito, alegre, vibrante e mágico de religiões que muitas vezes foram vistas pejorativamente como "magia negra" ou "macumba".

\section{O Canto da Sabiá}

A análise da obra de Clara Nunes, sob a perspectiva da presença das religiões afro-brasileiras na $\mathrm{MPB}$, completa-se com a interpretação dos textos presentes nas letras das músicas que compuseram seu repertório e fazem, explicitamente, menção ao universo religioso afro-brasileiro.

Sabe-se que Clara não era uma compositora, sua arte era interpretar canções de outros. Apesar disso, a interpretação, a qual dava às músicas que gravou, foi tão marcante, que logo se estabeleceu uma profunda identificação entre a cantora e a música, a ponto dessas canções se transformarem, para o público que as consumia, em "músicas da Clara".

Os próprios compositores das canções que Clara Nunes gravou reconhecem essa identificação e dão crédito à cantora. Segundo reportagem de Isa Cambará publicada na Folha de São Paulo de 23/09/1982, Chico Buarque dizia que Clara não era intérprete, mas parceira, pois quando cantava transformava a canção.

Por isso, apesar de sabermos que as letras das músicas aqui analisadas não são de autoria da cantora, entendemos que o trabalho desenvolvido pela mesma na escolha de um repertório que traduzisse as propostas de sua carreira, mais a profunda identificação estabelecida entre a música e a intérprete, fazem dessas letras dados importantes para a compreensão não só da presença das religiões afro-brasileiras na obra da artista, com também a contribuição dessa obra na divulgação de um imaginário sobre essas religiões em espaços mais amplos da chamada "Cultura Nacional".

Também entendemos que aspectos musicológicos (melodia, ritmo, instrumentos musicais entre outros) presentes no repertório de Clara Nunes têm grande importância na relação estabelecida entre MPB e os terreiros de candomblé e umbanda. Contudo, optamos por priorizar a análise dos conteúdos simbólicos expressos nas letras das músicas cantadas por Clara Nunes.

As músicas do repertório de Clara, nas quais o candomblé e a umbanda aparecem, podem ser divididas em dois grandes grupos. No primeiro, a religião é abordada no plano do indivíduo explicitando as diversas relações que esse pode manter com os símbolos religiosos (mitos, ritos, valores etc.). Já no segundo, é o plano da sociedade que está em evidência, nela a religião aparece como um dos elementos que representa parte da identidade nacional. Obviamente, a divisão nesses dois grupos tem apenas uma finalidade analítica e muitas músicas 
podem participar igualmente de ambos. Abaixo, apresento algumas canções representativas de cada grupo.

As letras das músicas do primeiro grupo narram passagens da vida cotidiana como disputas amorosas, desentendimentos, comemorações etc. A religião aparece no cotidiano desse indivíduo, dando-lhe sentido, exprimindo um estilo de vida e um ethos próprio ao povo-de-santo.

Referências à magia freqüentemente estão presentes nesse grupo, explicitando como esta rege e explica as relações entre as pessoas e os fatos do cotidiano. A música "Mandinga" de Ataulfo Alves e Carlos Imperial, que Clara Nunes apresentou no Festival de Música de Juiz de Fora, em 1969, exemplifica bem isso. Nela, a mandinga, forma comum de se referir à magia no universo religioso afro-brasileiro, é o elemento essencial ao qual se recorre para resolver um problema de rejeição amorosa. Os orixás e as entidades, como os pretos velhos, são a quem se recorre para "curar" uma dor de amor. Em "Mandinga", o sujeito que sofre a dor do abandono recorre a Oxalá (o pai de todos os orixás muitas vezes sincretizado com Jesus Cristo, também Senhor do Bonfim na Bahia, a quem se recorre na "hora do aperto"), a Xangô (orixá da justiça que pode ser justo com seu sentimento e trazer a pessoa amada de volta) e a Pai Joaquim (Preto Velho, entidade da umbanda que ajuda os fiéis), acreditando que a força dessas entidades é capaz de curar sua dor.

Até mandinga eu vou fazer, pra fazer você voltar/ Fiz promessa rezei tanto/ Me ajuda meu pai Oxalá/ Quem não foi nunca vai ser/ Que já é sempre será/ Gira o mundo/ Roda viva/ Na volta você vai voltar/ D'angola/ Malei me para ela/ D'angola a rosa para ela/ D'angola levo ao senhor do Bonfim/ D'angola Xangô na pedreira/ D’angola na minha aroeira/ D'angola saravá Pai Joaquim/ Dindindindindindim vamos saravá Pai Joaquim.

Nesse primeiro grupo ainda aparecem letras de músicas que são pontos de umbanda e candomblé estilizados, ou seja, adaptados para os parâmetros da indústria fonográfica tendo em média três minutos de duração. Ou ainda, letras que têm como tema central a própria religião, sendo uma espécie de ode ao universo religioso. Dentro desse grupo há uma diferença significativa entre aquelas músicas que na verdade são versões de músicas religiosas adaptadas por alguns compositores como Candeias, Romildo e Toninho, daquelas que são composições que se inspiram nos mitos, nas divindades e nos rituais do candomblé e da umbanda.

$\mathrm{Na}$ linha sobre estilizações de pontos de candomblé, Clara Nunes gravou uma das poucas cantigas do candomblé de angola que foram apropriadas pela MPB, "Sindorerê", uma adaptação feita por Candeias de um ponto de caboclo, 
entidade dessa modalidade de candomblé. A música apresenta várias referências aos inquices (nome que as entidades recebem na tradição banta da qual se origina o candomblé de angola), fala de Mutalambê, correspondente ao Oxóssi da tradição nagô, da jurema (árvore de onde se extrai uma bebida servida durante o toque de caboclo, essa planta ainda inspirou o nome de duas entidades, o Seu Juremeira e a Cabocla Jurema) e de Gangazumba, correspondente a Olodumarê, deus da criação ioruba.

Sindorerê/ Sindorerê/ Sindorerê, Sindorerê/ Sindorerê/ Sindorerê/ Sindorerê naruandê/ Sidoredê naruandá/ Oquê/ Sindorerê/ Sindorerê/ Oqueru oquê coquê/ Sindorerê/ Sindorerê/ Sindorê auê, auá/ Sindorerê tauê tauá/ Sindorerê/ Sindorerê/ Ele é sangue real/ Sindorerê/ Sindorerê/ Sindorerê no juremê/ Sindorerê no juremá/ Sindorerê/ Sindorerê/ Oqueru oquê coque/ Sindorerê/ Sindorerê/ Sindorerê Gangazumba/ Sindorerê naruerá/ Sindorerê/ Mutambá mutalambê/ Sindorerê/ Sindorerê/ Sindorerê meu tatamirô/ Sindoreê Etutalodó/ Sindorerê/ Sindorerê/ Sindorerê, Sindorerê/ Sindorerê/ Sindorerê.

Dentre as versões de músicas religiosas, também encontramos no repertório de Clara Nunes a música "Ê Baiana", de Fabrício da Silva, Baianinho, Ênio Santos Ribeiro e Miguel Pancrácio, que se tornou uns dos grandes sucessos da cantora. Essa música pode ter sido um ponto de umbanda gravado por Clara Nunes ou então uma música que ela cantou e mais tarde tenha se tornado uma música religiosa. O fato é que, durante a pesquisa, numa gira de baianos da Casa Espírita Ogum Beira Mar, localizada próxima à ponte do Piqueri em São Paulo, essa música foi ouvida numa sessão de passe de uma gira de baiano.

$\hat{E}$ Baiana/ÊE, ê, ê Baiana, Baianinha/Baiana boa/Gosta do samba/ Gosta da roda/E diz que é bamba/Olha toca viola que ela quer sambar/Ela gosta de samba/Ela quer rebolar/ Ê Baiana.

"Conto de Areia", segundo Severiano e Mello (Severiano \& Mello 1997), também é um ponto de umbanda estilizado. Diz a lenda que a sereia é um ser que habita os oceanos e com um maravilhoso canto enfeitiça os pescadores e os atrai para a morte. No universo popular praiano da Bahia, a sereia é uma das faces de Iemanjá, orixá que habita o mar e a quem os pescadores são devotos. A morte desses homens na atividade de pesca muitas vezes aparece metaforizada no "chamado de Iemanjá" que os leva para o fundo de seus domínios. Essa música conta exatamente isso, a dor de uma morena cujo amor era um canoeiro que morreu no mar. 
É água no mar, é maré cheia ô, mareia ô mareia/ É água no mar/ É água no mar é maré cheia ô mareia ô mareia/ Contam que toda tristeza que tem na Bahia/ Nasceu de uns olhos morenos molhados de mar/ Não sei se é conto de areia ou se é fantasia/ Que a luz da candeia alumia pra gente contar/ Um dia a morena enfeitada de rosas e rendas/ Abriu seu sorriso de moça e pediu pra dançar/ A noite emprestou as estrelas bordadas de prata/ E as águas de Amaralina eram gotas de luar/ Era um peito só cheio de promessa era só/ Era um peito só cheio de promessa era só/ Quem foi que mandou o seu amor se fazer de canoeiro/ $O$ vento que rola nas palmas arrasta o veleiro/ E leva pro meio das águas de Iemanjá/ E o mestre valente vagueia olhando pra areia sem poder chegar/ Adeus amor, adeus meu amor não me espere porque eu já vou me embora/ Pro reino que esconde os tesouros de minha senhora/ Desfia colares de conchas pra vida passar/ E deixa de olhar pro veleiro/ Adeus meu amor eu não vou mais voltar/ Foi beira-mar, foi beira-mar quem chamou/ Foi beira-mar ê, foi beira-mar.

O candomblé é uma religião que possui uma dimensão individual significativa, o adepto quando se inicia recebe um orixá com nome próprio que somente será "assentado" em sua cabeça, uma espécie de deus individual. Há altares particulares para os assentamentos do santo de cada pessoa pertencente ao terreiro e cada uma estabelece com seu orixá relações exclusivas e diretas que envolvem obrigações e satisfações de ambas as partes. Algumas músicas cantadas por Clara revelam elementos dessa relação. "Afoxé para Logun", por exemplo, é uma composição de Candeias que homenageia o orixá Logunedé. Nela, esse orixá é descrito mostrando suas qualidades (habilidade com a caça e a pesca), sua ascendência (filho de Oxóssi e Oxum) e sua condição de orixá meta-metá, ou seja, condensa em si a essência masculina e feminina. Também é explicitada a relação que o adepto estabelece com essa entidade, revelando as palavras que são usadas para saudá-lo ("Fará Logun, fará Logun, fá"), as oferendas que lhe são feitas (Axoxô, Onjé e Omolucum) e o que se espera em troca delas (o axé desse deus).

Menino caçador/ Flecha no mato bravio/ Menino pescador/ Pedra no fundo do rio/ Coroa reluzente/ Todo ouro sobre o azul/ Menino onipotente/ Meio Oxóssi meio Oxum/ É é é é é/ Quem é que ele é?/ Á á á á á/ Onde é que ele está?/ Axé, menino, axé/ Fará Logun, fará Logun, fá/ Menino meu amor/ Minha mãe, meu pai, meu filho/ Toma o teu axoxô/ Teu onjé de coco e milho/ Me dá o teu axé/ Que eu te dou teu omolocum/ Menino doce meu/ Meio Oxossi meio Oxum/ É,é,é,é,é. 
A música "Guerreira", composição de Paulo Cesar Pinheiro e João Nogueira, é o ponto de transição entre esse primeiro grupo de canções, no qual o plano do indivíduo e das relações desses com os símbolos religiosos é que estão em evidência, e o segundo grupo, no qual será a sociedade brasileira que estará em destaque. Nessa canção o sujeito é a própria Clara Nunes e a letra funciona como uma apresentação em que a cantora fala quem é e para que veio. Diz pertencer tanto a angola quanto a keto e nagô, que são, na verdade, os dois grandes modelos de culto seguidos pelas casas de candomblé no Brasil, o modelo angola baseado nas tradições bantas, e o modelo keto/nagô na iorubá. Logo ela seria uma herdeira das tradições africanas no Brasil. Com o seu canto ela espalharia essa tradição pelos sete cantos, ou seja, para todos os lados, sem temer feitiço, pois estaria protegida pelos orixás guerreiros, Ogum e Iansã. Do plano individual, que seria a sua herança pessoal e sua filiação religiosa, Clara passa para o plano da sociedade quando evoca o samba, exemplo de música brasileira por excelência, para falar de sua nacionalidade, da sua criação como cantora popular de expressão (lembremos que só começou a alcançar sucesso a partir do momento que passou a gravar sambas) e por fim de sua conversão tanto no sentido pessoal - momento que adotou a umbanda como religião - quanto no sentido artístico - momento em que adotou elementos da religiosidade afrobrasileira a fim de construir uma identidade artística. $O$ final desse canto é um ensinamento sobre o sincretismo religioso tão popular no Brasil, e que de alguma maneira também fez muito sentido na experiência religiosa da cantora que, embora tenha claramente se convertido à umbanda, continuou a transitar entre as religiões anteriores, catolicismo e espiritismo, e as novas, umbanda e candomblé. Ela saúda todo os orixás mais importantes do panteão ioruba e seus respectivos correspondentes na tradição católica.

Se vocês querem saber quem eu sou/ Eu sou a tal mineira/ Filha de angola, de ketu e nagô/ Não sou de brincadeira/ Canto pelos sete cantos não temo quebrantos porque eu sou guerreira/ Dentro do samba eu nasci/ Me criei e me converti/ E ninguém vai tombar a minha bandeira/ Bole com o samba que caio e balanço o balaio no som dos tantãs/ Rebolo que deito que rolo/ Me embalo e me embolo nos balangandãs/ Bambeia de lá que bambeio nesse bomboleio que eu sou bambambam/ Que samba não tem cambalacho vai de cima em baixo pra quem é seu fã/ Eu sambo pela noite inteira/ Até amanha de manhã/ Sou a Mineira Guerreira/ Filha de Ogum com Iansã/ Salve Nosso Senhor Jesus Cristo Epa Baba Oxalá/ Salva São Jorge Guerreiro Ogunhê, Ogum meu pai/ Salve Santa Bárbara Eparrei minha mãe Iansã/ Salve São Pedro Kaô Kabeci lê Xangô/ Salve São Sebastião Okê arô Oxossi/ Salve Nossa Senhora da Conceição Odô- 
Fiabá Iemanjá/ Salve Nossa Senhora das Graças Ora eieiei Oxum/ Salve Nossa Senhora de Santana Nanã Burokê Saluba Vovó/ Salve São Lázaro Atotô Obaluaiê/ Salve São Bartolomeu Arrobobô Oxumarê/ Salve o povo da rua/ Salve as crianças/ Salve os PretoVelhos/ Pai Antônio, Pai Joaquim d'Angola, Vovó Maria Conga/ Sarava/ E Salve o Rei Nagô.

As músicas que compõem o segundo grupo têm como tema central a construção de uma identidade brasileira. Aqui se percebe um claro tom de exaltação da identidade nacional que recupera o imaginário do "mito das três raças" de onde se depreende que o Brasil seria racial e culturalmente formado pela miscigenação das populações indígenas, africanas e européias. As religiões afro-brasileiras dentro dessa temática aparecem como marcas de uma herança africana impregnada na nossa música, nas nossas crenças, no nosso sangue etc.

No desenvolvimento da pesquisa não foram encontrados indícios de ligação entre a cantora e os movimentos sociais negros da época, conforme, por exemplo, ocorreu com outros artistas, como Martinho da Vila que teve atuação clara nesses movimentos. Clara tinha uma explícita preocupação em cantar coisas que representassem a cultura popular brasileira, e é nesse contexto que sua obra recupera o tema da miscigenação.

Em "Mãe África", composição de Sivuca e Paulo Cesar Pinheiro, gravada no LP Nação, Clara Nunes canta, acompanhada pela sanfona, o triângulo e a zabumba, a miscigenação racial. Preta-Bá, personagem que se refere à ama-deleite e representa a África, é a mãe que alimenta e ensina, dando leite e sangue para o filho, narrador da música que representa o Brasil de sangue nagô. A África também é lembrada na saudação às duas nações de candomblé, o keto ou iorubá, que representaria a tradição dos povos nagô, e o angola, que representaria a banta. $O$ "Filho Brasil" reconhece o legado e pede a bênção à "Mãe África" por meio de duas divindades iorubás, aqui popularizadas pelo candomblé, Xangô (orixá da justiça) e Oxalá (uma das principais divindades do panteão iorubá, responsável pela criação do homem).

No sertão mãe que me criou/ Leite seu nunca me serviu/ Preta-Bá foi que amamentou/ Fio meu e fio do meu fio/ No sertão a mãe preta me ensinou/ Tudo aqui nós que construiu/ Fio, tu tem sangue Nagô/ Como tem todo esse Brasil/ Oiê pros meus irmãos de Angola, África/ Oiê pra Moçambique e Congo, África/ Oiê pra toda nação Bantu, África/ Oiê do tempo de quilombo, África/ Pelo bastão de Xangô/ E o caxangá de Oxalá/Filho Brasil pede a bênção/ De MãeÁfrica. 
Na mesma linha de "Mãe África", a canção "Nanaê, Nana Naiana", de Sidney da Conceição, também retoma os tempos da escravidão e a relação estabelecida entre a ama-de-leite e o "sinhozinho" para falar das heranças africanas na cultura brasileira. Nanã Burokê, orixá da lama com a qual se fez o homem, em alguns mitos aparece, também, como orixá da justiça, a quem as mulheres recorrem para se defender dos maus tratos dos homens. Na música, a escrava se apega a Nanã Burokê para se defender da maldade do senhor, uma metáfora que apresenta a religião como elemento de resistência do negro à opressão do branco.

Além disso, essa mesma religião é também eleita como grande representante da herança negra dada à cultura brasileira. No trecho "sinhazinha mimada embalada no cantar da negra de Nananaê/ Herdou todo o seu ser/ Hoje, em noite de luanda, é a sinhazinha que vai dançar nananjangana", a música chama atenção para a difusão da religião e a transformação do candomblé, antes uma religião étnica, em uma de conversão universal.

Nanaê, Nanã Naiana, Nanaê ê ê/ Nanaê, Nanã Naiana/ Como manda irmã Nanã jangana/ Como manda irmã Nanã jangana/ Nanaê cantava pra sinhazinha dormir alue/ Pra ir pra debaixo do pé de café/ Fazer canjerê, Nanaê/ Se, sinhazinha acordasse/ Antes de Nanaê chegar/ E começasse a chorar/ Senhor mandava amarrar Nanaê/ E chibatar Nanaê/ Mas Nanaê se incorporava de Nanã Burokê/ E não sentia pancada doer, Nanaê/ Mas sinhazinha mimada embalada no cantar da negra de Nananaê/ Herdou todo o seu ser/ Hoje, em noite de luanda, é a sinhazinha que vai dançar nananjangana.

A temática da miscigenação será ainda mais uma vez abordada no repertório musical de Clara Nunes com o samba enredo "Tributos aos Orixás". Com um pedido de licença em iorubá (ago ilê), o sujeito da letra pede a Oxalá, o pai da cabeça, ou ori baba, para contar a vinda dos deuses africanos para cá. Os orixás transladaram para o Brasil nos corações dos escravos que a eles recorriam a fim de suportarem os suplícios da escravidão. Esses deuses africanos passaram, mais tarde, a fazer parte do panteão das religiões afro-brasileiras, sendo cultuados nos terreiros de umbanda e candomblé.

A letra desse samba enredo cumpre uma certa função didática explicitando vários termos próprios ao culto do candomblé. Adobá por exemplo é o nome dado a um movimento corpóreo que significa saudação. Então, na festa que é o carnaval, a escola vem saudar os orixás, começando com o senhor das matas Oxóssi, usando a expressão okê, grito que os devotos fazem para cumprimentar esse orixá. Em seguida, é a vez de Ogum ser lembrado pela sua capacidade de 
"vencer demandas" e por sua saudação guaru mifá. Nanã é evocada pela sua condição de mãe, cumprimentada pelo termo saluba. Já Iansã é lembrada como guerreira por seu grito forte epahei. Yalodê é um título que Oxum, senhora dos rios e cachoeiras recebe. Xangô é lembrado por sua força, simbolizado pela pedreira e saudado com a expressão kaô kabecilê. A rainha do mar, a mãe dos orixás não poderia ser esquecida, com odofiabá se saúda Iemanjá. Por fim, completando o panteão recordado pela música, está Obaluaiê, senhor das doenças, atotô.

Agô ilê, agô ilê, agô/ Mutumbá, mutumbá/ Pai maior ori babá/ Trazidos por navios negreiros do solo africano para o torrão brasileiro/ Os negros, escravos/ Entre os gemidos e lamentos de dor/ Traziam em seus corações sofridos/ Seus orixás de fé/ Hoje tão venerados no Brasil/ Nos rituais de umbanda e candomblé/ Nesse terreiro em festa/ Entre mil adobás/ Prestamos nossos tributos aos orixás/ Aos reis das matas, oquê bambokim/ Ao vencedor das demandas/ Guaru mifá/ Acacarucaia dos orixás/ Saluba/ A grande guerreira da lei, epahei/ Nos rios e nas cachoeiras, yalodê/ Ao dono da pedreira kaô, kaô/ A rainha do mar, odô-fiabá mamãe/ Ao curandeiro das pestes, atotô/ Agô ilê, agô ilê, agô/Mutumbá, mutumbá/Pai maior ori babá.

Durante a pesquisa, com a análise de todas as músicas que possuem referências às religiões afro-brasileiras em suas letras, pode-se perceber que dentre os elementos religiosos mais freqüentes encontram-se os nomes das entidades, depois referências à magia, aos atributos dos orixás e às nações de candomblé. O cruzamento das informações sobre os elementos mais constantes nas letras das músicas com a temática das mesmas nos permite delinear o que da religião é divulgado na $\mathrm{MPB}$, e o imaginário que resulta dessa divulgação. Primeiramente, essas músicas exercem uma função educativa, elas contam, ao seu modo, um pouco da história dos negros no Brasil, sua vinda da África e suas influências na cultura popular. Elas informam também sobre as religiões afrobrasileiras revelando suas principais divindades, as práticas mágica, os locais míticos, as comidas dos santos, os ritmos da música religiosa etc.

Ao gravar músicas com essa função didática, ela acabou por contribuir para a divulgação de uma visão de mundo própria da religião afro-brasileira revelando o caráter mágico e hedonista dessa religião.

\section{De cantora à "deusa dos orixás”}

No dia 5/03/1983, um sábado, Clara Nunes se internou na Clínica São Vicente, uma das mais bem conceituadas do Rio na época, para a realização de uma cirurgia de varizes de rotina. Tudo ia bem até que no final da operação a 
cantora teria sofrido um choque anafilático e, em decorrência disso, uma parada cardíaca que levou à falta de oxigênio no cérebro e, posteriormente, ao coma. Era o início de vinte oito dias de agonia que Clara sofreria até a sua morte, na madrugada da Sexta-feira Santa para o Sábado de Aleluia, dia 2/04/1983.

Devido ao clima de suspense, provocado pela divulgação de boletins médicos pouco explicativos, muitas foram as versões levantadas na imprensa sobre as circunstâncias da cirurgia e o que realmente teria causado a morte da cantora. Sua agonia e posteriormente morte se tornaram uma epopéia, minuciosamente relatada pelos meios de comunicação da época.

A clínica São Vicente virou local de peregrinação de pessoas famosas, jornalistas, parentes e fãs que lá iam a busca de notícias, mas quase sempre, nada de concreto era informado. Foi questionado se, realmente, Clara teria se internado para operar as varizes; se tinha sido vítima de choque anafilático ou de erro médico. Uma versão religiosa para o falecimento de Clara também foi levantada nesse período. Segundo informações presentes numa biografia da cantora (Fonte: www.geocities.com/SouthBeach/Bay/2796), Clara Nunes preferiu receber anestesia geral à peridural, mais indicada nesses casos, porque tinha o corpo fechado por Pai Edu que a proibiu de fazer qualquer incisão nas costas. Além disso, sua operação foi realizada durante a quaresma, momento em os terreiros, geralmente fecham, e nenhuma atividade religiosa é realizada, sendo um tabu, para os filhos de santo, submeterem-se à cirurgia nesse período. Essa versão se baseou principalmente nas advertências que Pai Edu teria feito a cantora, pouco antes do acontecido, através de uma reportagem da Revista Amiga. A edição da mesma revista do dia 20/04/1983 trouxe novas declarações de Pai Edu sobre o acontecido:

Não tenho culpa da morte de Clara. Imaginem! Apenas alertei para o risco que ela estava correndo, uma vez que estava ausente da minha casa. Mas ela poderia se cuidar com qualquer outro pai-desanto. A minha obrigação era alertá-la e já o tinha feito por telefone, duas vezes. Ela não estava se cuidando. Porque se estivesse se tratando com outro pai-de-santo, ele deveria ter lhe dado autorização para se submeter à operação. Comigo é que não foi. (...) $\bigcirc$ que me espantava era que ela foi coroada por mim como filha das águas (Oxum) e recebeu o título de Deusa das Águas porque todo trabalho foi feito no Rio Capibaribe. Depois de sua ausência do Palácio de Olinda, ela virou guerreira de Ogum com Iansã. Então, como é que eu poderia fazer alguma coisa por ela?

Rusgas entre Pai Edu e o marido de Clara eram antigas e vinham desde o casamento da cantora. Mas, desavenças religiosas à parte, fato é que Clara 
Nunes morreu no auge da sua profissão, aos 41 anos. A afeição que conquistou do público ao longo da carreira, aliada a uma imagem fortemente ligada à religião, mobilizou fãs, amigos e parentes que se agarraram às mais variadas expressões religiosas a espera de um milagre que a medicina não poderia mais realizar. Vários pais e mães-de-santo, assim como adeptos do candomblé e da umbanda, dirigiram-se para a porta da clínica a fim de realizar rituais de firmeza espiritual e vigília. Tentativas de tratamentos alternativos, como acupuntura, foram permitidas pela família, e quando já não restava mais esperanças o marido de Clara, segundo noticiado nos jornais da época, passou a receber dos fãs doações tais como pó de raspa do túmulo de Lázaro, águas milagrosas, folhas de árvore do pátio do Santuário de Fátima, óleos e azeites, crucifixos, breves, santinhos, poções e penas de ave.

A cantora foi velada no Portelão, quadra de sua escola de samba, Portela, com participação de cinco mil pessoas. Depois de um tumultuado velório seu corpo foi levado pelo carro de bombeiros até o cemitério São João Batista para ser sepultado em meio a uma outra confusão causada pelo enorme número de pessoas que lá compareceram.

Desde o dia seguinte a morte da cantora, seu túmulo se transformou num local de peregrinação do povo-de-santo. Segundo informações concedidas pelo senhor Varela, funcionário do cemitério que me acompanhou durante a visita que fiz ao túmulo, até hoje, no dia de sua morte e no dia de finados, um grande número de pessoas visita a sepultura de Clara, entre eles estão adeptos das religiões afro-brasileiras que levam seus atabaques e lá realizam rituais deixando, no fim, oferendas à cantora.

Para muitos, Clara Nunes não morreu, mas se encantou ascendendo assim ao status de uma entidade - Um Ser de $\mathrm{Luz}^{13}$ - como acontece com muitas personalidades do mundo afro-religioso. Por dois momentos foi possível constatar indícios dessa interpretação, o primeiro numa reportagem da Revista Tititi de 14/04/2003, na qual Dona Carmem Oliveira afirmou que fora curada de um câncer por Clara: "Já naquela época [período em que Clara morreu] eu sentia dor. Tinha uns nódulos nos seios. Que me preocupavam. No enterro comecei a rezar um terço, pedindo a ela que olhasse pela minha saúde". Num segundo, durante a visita ao túmulo, encontrei placas em que fiéis agradeciam à cantora as graças alcançadas.

Ainda hoje, as dimensões artística e religiosa presentes na vida de Clara continuam sendo referências para aqueles que compartilham o gosto por sua obra. Em espaços como o Fã Clube Virtual Clara Nunes, organizado por Eliane Lorenzo (atual presidente), há uma lista de discussão na qual as pessoas trocam e-mails sobre novidades, curiosidades e informações acerca da cantora. Uma quantidade significativa de e-mails revela que nesse local a dimensão religiosa ainda mantém forte presença, seja nos nicknames usados pelos participantes 
(Guerreiro de Oxalá, Babalorixá, Mingo ty Oya, pombagiraciganaloira, yalodofé entre outros), seja nos temas debatidos nos conteúdo dos e-mails (curiosidades sobre a experiência religiosa de Clara, declarações de quanto o exemplo de Clara foi importante na formação religiosa dessas pessoas, esclarecimentos sobre o que é a umbanda e o candomblé, informações sobre as entidades, declarações de pertencimento a essas religiões, transcrições de cantigas religiosas, "receitas de trabalhos mágicos" etc.), ou então, nos termos usados para saudar as pessoas no inicio ou no final do e-mail (saravá; eparrêi Yansãa odoyá ${ }^{14}$ minha mãe; Oxum okê; axé babá; okê, okê Nanã; entre outras).

\section{Algumas Considerações}

O projeto artístico elaborado por Adelzon Alves a fim de estruturar a carreira de Clara Nunes adotou a mestiçagem como ícone, e se espelhando na personagem de Carmen Miranda, cantou um Brasil mestiço, mas que era, sobretudo, negro. Foi nesse embalo que as religiões afro-brasileiras ganharam espaço não só na performance da cantora, como também em seu repertório que divulgou uma imagem bem específica dessas religiões.

Vale lembrar que o país se encontrava sob um regime ditatorial, instaurado pelo golpe militar de 1964. As transformações políticas e econômicas desse período, segundo Renato Ortiz (1985), alteraram a relação entre cultura e Estado; a política cultural implantada pelo estado autoritário brasileiro pós-64 causou um impacto efetivo sobre o mercado cultural influenciando o processo de mercantilização da cultura popular e levando a uma divisão entre cultura de massa e cultura artística.

Foi também, a partir dos anos 60, que se observou que o pluralismo cultural e a valorização étnica passaram a constituir a orientação tanto de produtores como de consumidores culturais. Nesse contexto, o elemento da mestiçagem é retomado como essência de uma cultura nacional, a unidade na diversidade.

É por meios do mecanismo de reinterpretação que o Estado, através de seus intelectuais, se apropria das práticas populares para apresentá-las como expressão da cultura nacional. O candomblé, o carnaval, as reisadas, etc, são desta forma, apropriados pelo discurso do Estado, que passa a considerá-los como manifestação de brasilidade. (Ortiz 1985:140)

Assim, no contexto dos anos de 1970, elementos culturais negros, como as chamadas religiões afro-brasileiras, adquiriram maior reconhecimento oficial. Caso paradigmático desse processo é relatado no trabalho de Jocélio Teles Santos, 
que demonstra minuciosamente as relações estabelecidas entre Estado e terreiros na Bahia para a construção de um discurso oficial sobre uma identidade regional que coloca o candomblé como elemento central dessa última.

O candomblé como algo 'exótico', atraente para o turismo, pode ser lido como uma revelação de que o país era uma soma diversificada, colorida e tropical de manifestações adstritas, mas não exclusivas, ao âmbito regional. Como bem nota Rubem Oliven, se desde o começo da década de sessenta o regionalismo, especialmente o nordestino, era um dos temas mais cadentes da nacionalidade, nos anos setenta, o Estado e os meios de comunicação se apropriam dessa temática. Em programas radiofônicos, divulgavam-se as músicas e os ternos de reis de algumas regiões brasileiras, com algo que precisava ser lembrado e valorizado. E nisto consistia a substituição de um modelo fundamentalmente baseado na coerção, por um outro ancorado na hegemonia, funcionando, basicamente, em termos de valorização de símbolos nacionais. É nessa direção que o uso de símbolos afro-religiosos pode ser enquadrado. (Santos 2005:134).

As influências africanas na cultura brasileira foram resgatadas pela indústria fonográfica que se mostrou mais interessada do que nunca nesses elementos culturais negros e eles se tornaram cada vez mais presente nas imagens e discursos de brasilidade oficial e comercial. O candomblé se expandiu adquirindo tal prestígio, que na década de 1980 se consolida como religião de conversão universal, deixando de ser uma religião exclusivamente de negros (Silva \& Amaral 1996). As artes (música, cinema, teatro, dança, etc.) buscaram nos elementos que remetem a um passado africano as novas referências e houve um grande aumento da produção e consumo de música com forte presença das temáticas afro-brasileiras, entre elas a religião.

No cenário musical nacional surgiu uma série de compositores e intérpretes que buscaram, na nascente "cultura afro-brasileira", os elementos para compor suas obras.

A partir da década de 60, com o questionamento e crítica das influências externas em nossa cultura e nos meios de comunicação de massa, surgem movimentos de conscientização política como os dos negros, e artísticos, como o tropicalismo, que revalorizam os temas nacionais. A cultura afro-brasileira entrou na moda nos grandes centros urbanos do sudeste, e artistas, nacionalmente reconhecidos, como Caetano Veloso, Gilberto Gil, Maria Bethânia, Vinícius de Moraes, Edu Lobo, Carlos Lira, Martinho da Vila, Clara 
Nunes e outros, em geral ligados ao candomblé e à umbanda, divulgaram nacionalmente os nomes e as lendas dos orixás. (Silva \& Amaral 1996:206)

Dentre esses artistas acima citados, Clara Nunes foi aquela que mais freqüente e explicitamente cantava músicas com temas ligados ao candomblé e a umbanda. A obra de Clara Nunes (seu repertório, sua performance em vídeos e shows, a personagem que criou para divulgar sua carreira, a própria forma que expôs, em revistas e jornais, suas experiências religiosas) é um exemplo paradigmático de como, via música, as religiões afro-brasileiras impregnaram a cultura nacional com seus valores, suas cores, seus orixás, seus ritmos.

Recuperando as trajetórias artística e religiosa da cantora, assim como a análise de sua obra, aqui apresentada, pode-se constatar como essas correspondem não só a formação do campo religioso afro-brasileiro, como também reproduzem uma visão positiva dessa religiosidade no âmbito da cultura nacional.

Sua primeira experiência religiosa foi no catolicismo, durante a infância, apenas na adolescência é que teve os primeiros contatos com o espiritismo, quando sua família se converteu ao kardecismo. Nessa primeira experiência com o espiritismo, Clara conheceu um kardecismo tradicional, praticado em Minas, fortemente influenciado pelos ensinamentos do médium Chico Xavier, que pregava o modelo católico de santidade (sofrimento, renúncia, pobreza e caridade).

Somente numa fase posterior da sua vida, Clara Nunes se converteu a umbanda com o batismo no Rio Capibaribe. Sua inserção nessa religião ocorreu em dois lugares específicos, inicialmente no terreiro de Pai Edu uma casa de xangô pernambucano ${ }^{15}$, e mais tarde nos terreiros cariocas, em especial o de Vovó Maria Joana Rezadeira. Com isso a cantora teve contato tanto com práticas influenciadas pela tradição banta (a umbanda e a macumba do Rio de Janeiro) quanto pela iorubá (o xangô pernambucano).

$\mathrm{Na}$ época da conversão de Clara Nunes, havia uma maior valorização da tradição iorubá em relação à banta, em especial os terreiros nagôs baianos (Gantois, Casa Branca e Opô Afonjá) - que serviram de exemplo para a elaboração de etnografias clássicas sobre o culto do candomblé no Brasil nas quais essas práticas foram consideradas mais "puras" por uma série de intelectuais desde os anos de 1940; entre eles: Arthur Ramos, Roger Bastide e Pierre Verger, o que conferiu a esses terreiros notoriedade e legitimação. Por isso, as práticas iorubás eram mais valorizadas e apareciam com mais freqüência nas músicas, nas peças de teatro, nas tramas das novelas, nos enredos de escola de samba etc. Isso ocorreu principalmente na MPB produzida nessa época, sendo muito menor a referência à tradição angola em relação à nagô ricamente detalha nos trabalhos de Vinícius de Morais, Baden Powell, Caetano Veloso, Gilberto Gil, Maria Bethânia, João Bosco e Aldir Blanc, entre outros. 
Talvez por ter tido uma experiência pessoal marcada pelo trânsito entre as chamadas "religiões espíritas" no Brasil, e assim também ter entrado em contato com as práticas bantas, Clara foi uma das poucas artistas que tem em seu repertório referências ao candomblé angola e as entidades bantas. Uma outra característica do repertório de Clara Nunes é que quando as mais variadas práticas bantas e iorubás aparecem juntas numa música, não há entre elas uma relação hierárquica, assim como também não há uma relação hierárquica entre candomblé e umbanda. Todas são descritas de forma positiva, e nenhuma se sobrepõe a outra. Exemplos do que foi dito pode ser encontrado em duas músicas, "Banho de Manjericão" e "Nação". Na primeira as práticas mágicas da umbanda são descritas de forma bem positiva, valorizando o poder de cura dessa religião, além disso, a umbanda aparece no mesmo nível hierárquico do cristianismo. Já na segunda, Clara declara pertencer a todas as nações, Angola, Keto e Nagô, sem distinção e ao final saúda tanto orixás, quanto pretos velhos, sem colocálos numa relação de desigualdade.

Em vida, Clara Nunes foi uma grande divulgadora das religiões afrobrasileiras cantando um repertório que esmiuçou esse universo religioso revelando um "Brasil Mestiço". Após sua morte, ao passar de cantora à "Deusa dos Orixás", sua obra continua sendo referência incentivando a propagação das religiões que tanto cantou.

O tipo de análise aqui proposta procurou fugir do olhar dominante nos estudos sobre candomblé e umbanda porque se propõe entender essas religiões fora de seus espaços típicos de manifestação. $O$ que estava em foco não era o campo religioso afro-brasileiro em si, com seus adeptos e suas dinâmicas, mas os diálogos estabelecidos entre essas religiões com outros campos da cultura nacional, no caso a música popular.

A intenção era "explorar algumas das muitas formas pelas quais seus símbolos [da religião], artefatos, valores projetos e questões se constituem e colaboram para construir e transformar os cenários sociais e políticos de que participam" (Birman 2003:12). Nesse sentido, o exemplo de Clara Nunes se torna bastante interessante porque através da obra dessa artista se pôde explorar a construção de um diálogo ente campos religiosos e o da música popular, que ajudou na divulgação positiva de religiões historicamente perseguidas, e possibilitou uma nova compreensão das mesmas.

\section{Referências Bibliográficas}

AMARAL, Rita \& SILVA, Vagner Gonçalves da. (2006), "Foi conta para todo canto: As religiões afro-brasileiras nas letras do repertório musical popular brasileiro". Afro-Ásia, n. 34, pp: 189-235. Disponível em: http://www.afroasia.ufba.br/edicao.php? $\operatorname{codEd}=87$ 
BIRMAN, Patrícia. (org.) (2003), Religião e Espaço Público. São Paulo: Attar.

BRANDÃ O, Maria do Carmo \& MOTTA, Roberto. (2002), "Adão e Abadia: carisma e tradição no xangô de Pernambuco". In: V. G. da Silva (org). Memória Afro-brasileira: caminhos da alma. São Paulo: Selo Negro.

MOURA, Roberto. (1983), Tia Ciata e a Pequena África no Rio de Janeiro. Rio de Janeiro: FUNARTE. ORTIZ, Renato. (1985), Cultura brasileira e identidade nacional. São Paulo: Brasiliense.

PRANDI, Reginaldo. (2000), "De africano a afro-brasileiro: etnia, identidade, religião". Revista USP, no $46: 52-65$.

SANDRONI, Carlos. (2001), Feitiço Decente: Transformações do samba no Rio de Janeiro (1917-1933). Rio de Janeiro: Jorge Zahar Editor/ Editora UFRJ.

SANTOS, Jocélio Teles dos. (2005), O poder da cultura e a cultura no poder: a disputa simbólica da herança cultural negra no Brasil. Salvador: Edufba.

SEVERIANO, Jairo \& MELLO, Zuza Homem de. (1997), A Canção no Tempo: 85 anos de música brasileira. São Paulo: Editora 34. Vol. 1 e 2.

SILVA, Vagner Gonçalves da. (1995), Orixás da Metrópole. Petrópolis: Vozes.

SILVA, Vagner Gonçalves da. e AMARAL, Rita. (1996), "Símbolos da herança africana: Por que candomblé”. In: L. Schwarcz \& L. Reis (orgs.) Negras Imagens. Ensaios sobre escravidão e cultura. São Paulo: Edusp e Estação Ciência.

SODRÉ, Muniz. (1979), Samba: O dono do corpo. Rio de Janeiro: Mauad.

\section{Periódicos Consultados}

Jornal do Brasil edição publicada em 19/09/1973

Jornal Folha de São Paulo edição publicada em 11/05/1973

Jornal Folha de São Paulo edição publicada em 11/09/1975

Jornal Folha de São Paulo edição publicada em 09/05/1977

Jornal Folha de São Paulo edição publicada em 23/09/1982

Revista Amiga edição n674 publicada em 20/04/1983

Revista Tititi, ano VI n 240, publicada em 14/04/2003

\section{Fontes Digitais Consultadas}

www.claraguerreira.hpg.ig.com.br/biografia.htm/. Consultado em 05/2003

www.geocities.com/SouthBeach/Bay/2796/index2.html/. Consultado em 05/2003

www.opovo.com.br/. Consultado em 04/2003

\section{Notas}

* Esse texto é baseado em minha dissertação de mestrado defendida em outubro de 2005 no PPGAS/ USP. Gostaria de agradecer aos professores Vagner Gonçalves da Silva, meu orientador, Rita de Cássia Amaral, pela sugestões e aprendizado, sobretudo durante o período de minha Iniciação Científica, Silvia Caiuby Novaes e Letícia Reis Vidor, membros da banca, pelas leituras cuidadosas, críticas e sugestões. Agradeço também a Eliane Lorenzo e Santelmo Camilo, fãs e colecionadores da obra de Clara Nunes, que gentilmente cederam material imprescindível a este trabalho.

1 Há uma discussão entre os fãs de Clara Nunes, salientada principalmente por Neide Pessoa, jornalista e gerente do Grupo Clara Nunes, de que na verdade a cantora teria nascido em 1942. Porém, os dados oficiais apontam o ano de 1943 (conforme consta na lápide do túmulo da artista); optamos pela versão oficial. 
2 Histórias como a de Pai Adão, babalorixá recifense que exerceu importante papel na consolidação do xangô pernambucano e cuja reputação e legitimidade como sacerdote foi construída a partir de uma longa estada na África, e de Martiniano do Bonfim, que após um período na África implementou no terreiro Opô Afonjá os cargos de Obá de Xangô; são paradigmáticas da força simbólica que o "retorno à África" pode ter nessas religiões.

3 O jornalista Gilberto Nahum escreveu um artigo no Jornal Folha de São Paulo de 11/05/1973 em que dizia: "Clara é a cantora dos candomblés, é a cantora de sua gente que vai ao teatro lhe levar oferendas. Ela se emociona, chora enquanto uma garota de 9 anos lhe pede benção e lhe entrega um presente."

4 Todas as reportagens de jornal citadas nesse artigo encontram-se no arquivo do Jornal Folha de São Paulo, Pasta Clara Nunes.

5 Em entrevista concedida durante pesquisa de campo, Pai Edu nos informou que como todo artista, Clara Nunes tinha começado o processo de iniciação, mas que não havia "feito o santo total" por não poder se afastar dos compromissos profissionais por um longo período.

6 Abóbora é uma comida de Iansã e por isso sua ingestão é um tabu para os filhos dessa divindade.

7 Nesse show, Clara Nunes vestia uma roupa diferente a cada dia para homenagear o santo do dia. Na reportagem publicada pelo Jornal do Brasil em 19/09/1973 a cantora dizia: "Sou uma filha-desanto que realmente obedece a todas as obrigações. Na quarta-feira me visto de vermelho [cor de Iansã], embora na primeira parte apareço de branco, porque é a cor que eu mais aprecio. Na quinta estou de verde [cor de Oxóssi], na sexta, de branco [cor de Oxalá], no sábado de amarelo ou azul, as cores de Oxum e Iemanjá. No domingo eu saio de Nanã [cor lilás], que é a mãe de todos os outros".

8 Espaço público dos terreiros onde geralmente se realizam as cerimônias públicas dessas religiões como as festas de santo, de saída de iaô, entre outras.

9 Ogã alabê é o cargo hierárquico ocupado pelos músicos no candomblé.

10 "Xirê é uma estrutura seqüencial de cantigas para todos os orixás cultuados na casa ou mesmo pela 'nação' indo de Exu a Oxalá." (Silva 1995:142).

${ }^{11}$ Roncó é o quarto de santo, para onde os filhos de santo são levados após entrarem em transe para vestirem as indumentárias de seus orixás.

${ }^{12}$ O ijexá é um ritmo típico do candomblé ketu tocado para Oxum.

${ }^{13}$ Vale notar que Ser de Luz, além de ser um dos apelidos da cantora, também é um termo usado no espiritismo kardecista para se referir às entidades do Bem.

${ }^{14}$ Expressão usada para saudar Iemanjá.

${ }^{15}$ Esse é o nome pelo qual a modalidade de culto afro-brasileiro é conhecida em Pernambuco. Ao que parece o terreiro de Pai Edu abriga tanto rituais de candomblé quanto de umbanda como outros terreiros de xangô parecem também fazer. Para maiores informações ver Brandão \& Motta (2002).

Recebido em março de 2007

Aprovado em julho de 2007

Rachel R. B. Bakke (rachelrua@gmail.com)

Formada em Ciências Sociais na USP, em 2005 obteve título de mestre em antropologia social estudando as relações entre as religiões afro-brasileiras e a MPB. Atualmente faz seu doutoramento cujo tema é as representações das religiões afro-brasileiras presentes no ensino de cultura afro-brasileira após a lei 10.639/2003, com apoio da FAPESP. 


\section{Resumo:}

Algumas informações sobre as religióes afro-brasileiras (candomblé e umbanda) nos chegam por meios como a indústria fonográfica, o rádio e a televisão. Nesse cenário, a música popular brasileira (MPB) ocupa importante papel de divulgadora dessa religiosidade. Em vista disso, nesse trabalho procuro interpretar os modos pelos quais os valores dessas religiões aparecem na MPB tendo como campo empírico a produção artística de Clara Nunes (análise de letra de música, da performance em shows, clipes e apresentações em programas de TV, assim como dos símbolos escolhidos na divulgação de seu trabalho, presentes em encartes e capas de LPs).

Palavras-chave: religiões afro-brasileiras, música popular.

\section{Abstract:}

Information about Afro-Brazilian religions (candomblé and umbanda) often reaches the general public through the phonographic industry, radio and television. Brazilian Popular Music (MPB) is also an important source of information about these religions. For this reason this paper attempts to interpret the ways in which the values from these religions appear on MPB, having as an empirical field the artistic production of Clara Nunes (analyzes of lyrics, performances in concerts, video clips and appearances in TV shows, as well as the symbols chosen to disseminate her work, shown in LP covers and inner-sleeves)

Keywords: Afro-Brazilian religion, popular music. 